\title{
"JEG ER KØBMAND OG IKKE FILOSOF" Sex, handel og venskab mellem kristne og muslimer i Boccaccios Decameron
}

I modsætning til Italiens to andre store 1300-talsdigtere, Dante og Petrarca, tildeler Giovanni Boccaccio (1313-1375) handelskulturen en central plads i sit hovedværk. Dante fordømte den grådighed, som handel fik frem i mennesket, avaritia, en af de syv dødssynder, som allerede de tidligste fortolkere, heriblandt Boccaccio, så symboliseret i den ulv, der sammen med to andre dyr blokerer vejen for Dante i Komediens indledende sang. I Helvede møder Dante mange af sine landsmænd fra Firenze, og da et par af dem spørger, om der stadig hersker "høviskhed og tapre dyder" (Dante XVI v. 66) i byen efter deres død, udbryder han: "Vé dig Firenze, som du nu må græde!/Opkomlinge og hurtigt tjente penge:/umådehold og hovmod har de bragt dig!" (Dante XVI v. 73-75). Også Petrarca opfattede handel og pengesager som underlødige og beskæftigede sig ikke med handel i sin digtning (Branca 135). I Decameron (1348-52) finder vi derimod et sekulært livssyn, hvor de kirkelige institutioner kun optræder for at blive latterliggjort for deres hykleri og korruption. I stedet hyldes menneskets intellektuelle dyder, "virtù", som redskaber til at overkomme de forhindringer, som skæbnen, naturen eller kærligheden, under ét "Fortuna", udgør. Også menneskets evne til via flid og opfindsomhed at tjene penge tematiseres, og værket er blevet kaldt et købmandsstandens 
epos af Boccaccioforskeren Vittore Branca, opkaldt efter "de mænd som mest magtfuldt har sat deres aftryk på civilisationen" (Branca 153) og som med deres åbne mentalitet og ambitioner udgjorde det mediterrane Europas avantgarde (Branca 136).

Med et spil på Balzacs Comédie humaine gav Branca Decameron tilnavnet den "menneskelige komedie" for at fremhæve forskellen i forhold til Dantes Komedie, som netop Boccaccio havde givet tilnavnet "guddommelig". Udover at tematisere handel, rigdom og penge, er også Decamerons tilblivelse knyttet til handelskulturen: Værket henvendte sig til det nye publikum af købmænd og håndværkere, som var begyndt at læse og skrive og ønskede en litteratur, der hverken besang fortiden (som helteepos) eller var kristen og opbyggelig (som de latinske exempla), men som kunne underholde på folkesprog.

Handel var den væsentligste årsag til de italienske bystaters udvikling i senmiddelalderen: På Boccaccios tid havde den florentinske møntenhed, florinen, overgået den byzantinske hyperpyron og de arabiske dinarer og var blevet tidens stærkeste valuta (Branca 137). ${ }^{1}$ Købmandsstanden udviklede sig til et handelsborgerskab med indflydelse på samfundsudviklingen. Handelsmænd, entreprenører, læger og advokater fik magt (Bardi, Acciaioli, Peruzzi) og udfordrede den privilegerede position, som de aristokratiske familier i Firenze (Cerchi, Donati, Medici) havde haft. I slutningen af det 11. århundrede havde havnebyerne Pisa, Genova, Venedig og Napoli udviklet sig til handelscentre på lige fod med Firenze, ikke mindst takket være deres handel med den byzantinske og islamiske verden. Napoli handlede med Nordafrika og Orienten. Amalfi havde handelskolonier i Konstantinopel og skibe der lagde til i Tunis, Egypten og Syrien. Blandt toskanerne var Boccaccios Firenze den mest aktive by i handlen med Orienten. Det var ikke en søfartsnation, men den internationale handel medførte et behov for at veksle og transportere kapital, som de florentinske bankfirmaer specialiserede sig i (Simon 94). De havde agenter i Beirut, Aleksandria og Damaskus og handlede med Nordafrika, Konstantinopel, Kina og Indien. De importerede luksusvarer (medicin, tekstiler, farver) og eksporterede krydderier

1 Boccaccio fik formentlig selv praktisk erfaring med handel under sit ophold i Napoli som ung, hvor han arbejdede for farens firma, Bardi (Branca XLII). 
og tekstiler (Simon 97), tjente penge på transport af slaver og på at fragte kristne pilgrimme til Jerusalem og muslimske til Mekka.

I det følgende vil jeg undersøge, hvilken rolle handelskulturen spiller for billedet af muslimer og islamisk kultur. Min analyse er inspireret af Vittore Branca og suppleret med nyere analyser af især Anita Simon (1999) og Sharon Kinoshita og Jason Jacobs (2007). Jeg vil argumentere for, at handel i Decameron skaber kontakt på tværs af religiøse forskelle og politiske konflikter, at fremstillingen af muslimer er mindre fordømmende end hos Dante og Petrarca, at den orientalske verden skildres som sted for opnåelse af rigdom og succes, samt at den indirekte fremstår som et sted, hvorfra der kan kastes et kritisk blik på Europa. ${ }^{2}$ Konkret vil jeg analysere to af de noveller, der fortælles på andendagen. Det drejer sig ikke om at bruge novellerne som direkte kilder til viden om handelskulturen i lighed med den gren af Boccaccio-forskningen, som ifølge Kurt Flasch abonnerer på "legenden om realisme" hos Boccaccio og som han tager forbehold for i bogen Poesia dopo la peste (1995). Jeg er således enig i, at i Decameron "bliver de realistiske detaljer udvalgt og ordnet med en moralsk hensigt, der står over enhver interesse for den empiriske kendsgerning" (Flasch 126); novellerne omhandler begivenheder, som kunne ske i virkeligheden, og skal ikke forstås som en realistisk gengivelse af ting, der er sket (Flasch 125). Jeg mener dog ikke, at denne opfattelse udelukker en læsning, som tillægger novellernes inddragelse af konkrete geografiske steder et ekstra betydningsniveau og dermed viser, hvordan novellerne er præget af periodens handelskultur i både tematisk indhold og narrativ struktur. ${ }^{3}$

\section{HANDEL OG SAMKVEM MED DEN}

\section{ISLAMISKE VERDEN I DECAMERON}

Decamerons geografi fortæller i sig selv en historie om Italiens handel med bl.a. den islamiske verden: Novellerne udfolder et kæmpe geografisk områ-

2 Se Lausten "Alt bliver til i strid" om Petrarcas syn på islam. Se Ziolkowski for en behandling af Dantes forhold til islam.

3 Jeg ønsker at takke redaktionen og den anonyme 'reviewer' for god og konstruktiv kritik. 
de fra London, Algarve og Calais i vest til Konstantinopel og Kappadokien i øst, fra Kairo og Aleksandria til en lang række italienske byer. Det er hovedsageligt et mediterrant univers med en overvægt af italienske, græske og nordafrikanske byer, der forbindes af de rejser, novellerne ofte er bygget op omkring, rejser der følger de samme ruter, som virkelighedens handelsmænd fulgte. Kilderne bag novellerne vidner ligeledes om kontakten med den orientalske verden, idet Boccaccio låner motiver både fra den vestlige og den orientalske fortælletradition. Orientalske fortællinger fra værker som Sendebar (også kaldet Sindbads bog eller De syv vise), Kalila og Dimna, Disciplina Clericalis og Barlaam og Josaphat cirkulerede i Sydeuropa via omrejsende købmænd, pilgrimme og korsfarere. Fortællingerne fulgte på sin vis de samme ruter som andre varer i området og nåede de europæiske folkesprog via oversættelsesaktiviteter i Spanien, hvor jøder, kristne og muslimer virkede ved hoffet i Toledo, og i mindre grad på Sicilien, ved Frederik II's hof. Den muslimske verden fungerede som et mellemled mellem Europa og det fjerne østen, Indien og Kina. Det er blevet diskuteret, om disse orientalske fortællesamlinger - som alle er rammefortællinger - gav Boccaccio inspiration til selve rammestrukturen i Decameron udover at afgive motiver til mange af novellerne. ${ }^{4}$

Boccaccio hylder den nye, driftige samfundsklasse, men han fremhæver samtidig dens begrænsninger: han tematiserer modsætningen mellem de etisk korrekte, medmenneskelige værdier på den ene side, som han fandt i tidligere tiders (og litterære værkers) høviske adfærd, og de kyniske aspekter ved det nye samfund, hvor profit og egeninteresser kommer før alt andet på den anden side. Ligesom det gælder for andre af Decamerons gennemgående temaer (som fx kvindeopfattelsen), er det svært at nå frem til en entydig fortolkning af værkets værdisystem. Det skyldes bl.a. dets

4 Se Varvaro, Picone og Pioletti som argumenterer for den orientalske påvirkning, og se Toftgaard (99-100), der giver et overblik over dette spørgsmål og desuden fremhæver en episode i Ovids Forvandlinger som en anden mulig inspiration til rammestrukturen. I de noveller fra Decameron som vil blive omtalt i det følgende, skyldes tematiseringen af muslimske personer og steder ikke, at der ligger en orientalsk kilde bag fortællingen. Der findes kun sikre kilder til halvdelen af novellerne, blandt andet fordi mange af dem er mundtligt overleverede og fordi kilden er blevet grundlæggende ændret af Boccaccio. 
karakter af rammeværk med flere forskellige fortællere, der udtrykker hver deres holdning til historierne og til tider modsiger hinanden. ${ }^{5}$

I forhold til den islamiske verden, er alle de historiske kontakter til stede i værket (missionærer, korsfarere, pirater, handelsmænd), men de fleste møder mellem kristne og muslimer skildres som et resultat af handelskulturen. Handel udgør ofte det narrative greb, der muliggør møderne: markedspladsen fungerer som et mødested i konkret og overført forstand. Man kan, som Janet Smarr gør, skelne mellem tre narrative strategier for kulturmøderne: Muslimer, der rejser til Europa og knytter venskaber med kristne som Alatiel (II, 7) og sultan Saladin (X, 9); ikke-kristne personer i Asien eller Nordafrika, som jøden Melkisedek og sultan Saladin i Aleksandria (I, 3); kristne, der rejser til den islamiske verden, som Zinevra fra Genova der rejser til Aleksandria (II, 9), Gostanza fra Lipari der kommer til Tunis (V, 2) og Torello som rejser til sultanens hof i Egypten (X, 9). Vi møder kun italienske handelsmænd i den islamiske verden og ikke muslimske handelsmænd i Italien, og måske svarer det ganske godt til de faktiske forhold i perioden, hvor der reelt ikke kom mange muslimske købmænd til Italien: Den arabiske kultur var også en handelskultur med omrejsende købmænd, men det var, ifølge historikeren David Abulafia, de vestlige købmænd, der åbnede handelsmarkederne i østen, snarere end muslimske købmænd der rejste til vesten (Abulafia 5).

I Decameron bliver den islamiske verden udelukkende positivt beskrevet for sin rigdom, generøsitet og retfærdighed. Det ses i novellen om købmand Torello (X, 9), der har taget generøst imod sultan Saladin i Italien og som senere, da han er i fængsel i Aleksandria, nyder godt af sultanens venskab og derfor vender hjem til Pavia belæsset med "guldstykker, kostbare stene og andre smykker" og "et sværd med uvurderlige prydelser" (X, 9: 853-4). ${ }^{6}$ Det ses i II, 9 om Zinevra og hendes mand, der vender hjem fra Aleksandria med penge og gaver fra den egyptiske sultan. Og det ses i historien om Gostanza

5 Man kan helt overordnet skelne mellem tre niveauer: den ydre ramme hvor den implicitte forfatter taler (fortalen, indledningen, indledningen til den fjerde dag, og konklusionen), de hundrede noveller hvor de ti fortællere taler, og de historier som fortælles af personer i novellerne (for en uddybning se Toftgaard 80-1).

6 Jeg citerer på nær få undtagelser fra J.V. Linds danske oversættelse af Decameron fra 1960. Se Boccacio, Dekameron. 
og Martuccio $(\mathrm{V}, 2)$, som begynder på den sicilianske ø Lipari "for ikke længe siden", hvor Martuccio, der er for fattig til at gifte sig med Gostanza, sejler ud, bedriver fribytteri og bliver rig. Martuccio havner i fængsel i Tunis, men hjælper landets konge og belønnes med frihed og gaver. Gostanza tror på sin side, at Martuccio er omkommet og sejler alene ud på havet for at dø. Hun driver i land i Tunis, hvor to kvinder tager sig af hende. Hun lærer arabisk og arbejder med en gruppe saracenske kvinder, der laver "forskellige ting af silke, palmeblade og læder" (V, 2: 411). Ligesom handelen med Orienten bragte rigdom til Italien, bringer mødet med den islamiske kultur rigdom til novellernes hovedpersoner. De møder generøse og gæstfri folk og realiserer deres ønsker om kærlighed og rigdom. Hertil kommer, at den muslimske andethed markeres ganske objektivt i Decameron. I femte dags anden novelle oplyses det $\mathrm{fx}$, at saracenerne benyttede sig "mere af bueskytter end af andre krigsfolk" (V, 2: 412), en kendsgerning der giver Martuccio anledning til at hjælpe kongen af Tunis. Til sammenligning bruges den samme information til at nedgøre de orientalske folk i et digt af Boccaccios ven og forbillede Francesco Petrarca (1304-74) (jf. Lausten, "Alt bliver til i strid" 58-86).

To noveller i særdeleshed er interessante ud fra dette perspektiv, da man her finder en sammenfletning af køn, sex, handel og kulturmøde i Middelhavet: historien om den egyptiske prinsesse Alatiel (II, 7) og den om Zinevra, der rejser til Aleksandria forklædt som en handelsmand (II, 9). Begge noveller bliver fortalt på andendagen, hvor det handler om personer, der opnår uventet lykke efter at have lidt meget. Kvinderne i begge noveller er udsat for en voldelig patriarkalsk verden, som de med snuhed og kløgt formår at klare sig i. Som led i løsningen på de kriser de udsættes for, leger de med sprog og identitet, de bliver 'en anden' i uderummet end den de var, og kan til slut vende hjem og tilbage til deres oprindelige identitet. I novellerne optræder handelskulturen - og forholdet til den islamiske verden - som bagvedliggende logik og direkte tema.

KøN OG KULTURMØDE (II, 7)

Anden dags syvende novelle rummer, ligesom Decameron, flere fortællinger i én: selve rammefortællingen, hvori sultanen af Babylon forærer sin smukke datter, Alatiel, til kongen af Algarbien (svarende til Algarve i dag og 
dengang den nordligste provins af Marokko) som tak for, at han har hjulpet ham i en krig. Skibet med Alatiel ombord stævner ud fra Aleksandria, men forulykker i en storm ud for Mallorca. Her starter den næste fortælling om Alatiels videre rejse, som personerne i rammen aldrig lærer at kende (ligesom folk i Firenze aldrig hører om de ti fortælleres oplevelser ude på landet). Mændene på båden redder sig selv og lader prinsessen og hendes damer drive ind mod kysten. En lokal adelsmand hjælper dem, men forfører Alatiel og bliver den første i rækken af ni mænd, som hun har kortere eller længere seksuelle forhold til. I løbet af fire år har hun sex med mændene "titusinder gange", som det lyder eventyragtigt til slut, og det fremhæves ofte, at hun finder stor nydelse i disse forhold. Adelsmandens bror forelsker sig i Alatiel og dræber sin bror for at bortføre hende med skib. Han bliver kastet overbord af to genovesiske handelsmænd, som derefter kæmper om hende. Den overlevende tager hende med til Chiarenza på den græske halvø Peloponnes, hvor hun bliver overtaget af fyrsten af Morea. Denne bliver slået ihjel af hertugen af Athen, hvilket fører til en krig, som kejseren af Konstantinopel blander sig i ved at sende sin søn Costanzo afsted for at hjælpe Athen. Men Costanzo kidnapper selv Alatiel og tager til Chios, hvor han dog bliver besejret af tyrkernes konge, Osbech, som fører Alatiel til Smyrna og overlader hende til sin tjener Antioco. Da Antioco dør, sejler Alatiel med en købmand til Cypern, hvor hun genkender en mand fra sin fars hof, Antigono. Hun fortæller Antigono om sine oplevelser (hvilket på sin vis udgør en tredje historie i historien, som vi dog ikke hører direkte), men beklager sig nu over sin "vanskæbne" (II, 7:152) og hævder, at det havde været bedre, hvis hun var druknet end at have levet det liv hun har gjort i fire år. Antigono hjælper hende med at finde på en historie - novellens fjerde -, der fuldstændig afviger fra sandheden og derfor kan fortælles ved farens hof i Aleksandria og sørge for, at Alatiel vender hjem med æren og den oprindelige forlovelse i behold: "Munden der er blevet kysset, mister ikke sin kraft, ja den fornyr sig selv på samme vis som månen", som fortælleren hævder. ${ }^{7}$

7 Novellen har ligheder med en fortælling fra den orientalske fortælletradition ("Historien om elskerne fra Syrien") og i højere grad med en episode i en græsk roman af Xenophon fra Efesus (jf. Brancas note i Decameron 224, n.3, og jf. Picone 
Alatiel er genstand for et utæmmeligt begær, der overgår venskaber, familiebånd og militære alliancer, men hun bruger sin kløgt og opfindsomhed til at udnytte den situation, tilfældet har sat hende i. Novellen er en af Decamerons mest omdiskuterede bl.a. på grund af dens tvetydighed: Der gives en kontrast mellem Pamfilos indledende præsentation af Alatiels historie som en "ulykke" (hvilket hun som nævnt også selv bekræfter til slut) på den ene side og på den anden side dels hendes egen eksplicitte glæde ved sex, dels informationen om at de kvindelige lyttere sukker af længsel efter at opleve det samme. Hvem skal man tro? Moralen synes at være, at glæden ved erotik er vigtigere end at overholde normer for kyskhed. Men der gives også en kontrast mellem den komiske afslutning om hendes påståede kyskhed og den tragiske skæbne som de mange mænd lider efter at have kendt hende. Alatielfiguren er da også både blevet udlagt som en martyragtig kvinde, der for at overleve må afhumaniseres og overgive sig til mændene uden modstand (Marcus 7) og som en klog, aktiv og beregnende kvinde, der udnytter sin skønhed i en voldelig verden (Kahf 62). Hun forbliver ikke passiv, men overtager i novellens sidste del styringen af sit liv. Denne drejning sker ved hjælp af sproget, som det ofte er tilfældet i Boccaccios noveller.

Sproget har en betydning på flere planer. Måske er det netop fraværet af sprog, der forstærker mændenes forelskelse i hende (Marcus 6). De anvender, ligesom Alatiel, et mere sanseligt tegn- og kropssprog fremfor ordenes fornuft (Marcus 7). Manglen på fælles sprog er ellers en undtagelse i Decamerons univers, hvor personerne som regel forstår hinanden på trods af forskellige kulturelle og religiøse tilhørsforhold (som i novellerne IV, 4; $\mathrm{X}, 9$; II, 9). I denne novelle er der tale om et kunstgreb, der sikrer, at Alatiel undlader at afsløre sin identitet. Hun kommunikerer godt nok med sine sidste elskere, men afslører først sig selv overfor Antigono. Den løgn eller fiktion han hjælper hende med at formulere, genskaber hendes jomfruelige status i omverdenens øjne og genindsætter hende i den oprindelige sociale orden (Marcus 9).

1997 som analyserer novellens intertekstuelle forhold til den græske kilde). Begge kilder omhandler dydige og trofaste kvinder, mens Boccaccios novelle foretager en ironisk omvending af temaet. 
Novellen iscenesætter en sammenfletning af seksuel logik og handelslogik: Alatiels krop er tingsliggjort, hvilket rent sprogligt fremhæves ved, at hun gentagne gange betegnes som en "cosa": en "beundringsværdig ting" (mirabil cosa), en "vidunderlig ting" (maravigliosa cosa) og "sådan en smuk ting" (sì bella cosa) (Boccaccio, Decameron II,7:238). ${ }^{8}$ De to genovesiske sømænd planlægger eksplicit at købe hende i fællesskab, "som om man kunne behandle elskov som købmandsvarer og indtægter" (II, 7: 142), tilføjer fortælleren. Et gennemgående semantisk felt som vækst, støtter fortolkningen: Verbet "crescere" (at vokse) gentages både om mændenes kønsorganer og om handelsmændenes kapital (Kinoshita og Jacobs 172). Mændene i novellen er drevet af begær efter at få opfyldt både seksuelle og kommercielle behov. Deres transaktioner følger et merkantilt mønster og kvindekroppen reduceres til en vare, som kan opfylde deres behov, hun er en gave eller en ting, der gives som led i en strategisk udveksling eller kan overtages med vold. Mændene er styret mere af begær (efter rigdom og seksuel tilfredsstillelse) end af ideologi eller moralske principper (Kinoshita og Jacobs 186). Deres verden er præget af grådighed, selviskhed, vold og ambitioner, og den vægter en pragmatisk, økonomisk tankegang frem for en moralsk, religiøs. Det er kvindens skønhed og ikke hendes jomfrustatus, der tæller og tiltrækker mændene (når vi ser bort fra faren og hendes forlovede i rammehistorien). Det er også hendes adelige oprindelse, mændene er tiltrukket af: "Hendes fyrstelige udstyr viste straks prinsen, at hun måtte være af adelig stand, og hans kærlighed til hende fordobledes" (II, 7: 143). Når fortælleren Pamfilo i indledningen til historien advarer kvinderne mod at stræbe efter rigdom og skønhed frem for at "modtage og bevare det, der tildeles os" (II, 7: 137), ses endnu en tvetydighed: udsagnet henvender sig nemlig også til de mandlige læsere, der advares mod at følge deres begær efter rigdom.

Hvad angår billedet af islamisk kultur, beskrives Alatiels muslimske identitet neutralt: Hun danser på aleksandrinsk facon, hendes sprog er arabisk og hun drikker i princippet ikke vin, "fordi hendes love hidtil hav-

8 II, 7: 238. Jeg citerer undtagelsesvist fra Einaudis italienske udgave af Decameron, da den danske oversættelse ikke gengiver betegnelsen "cosa", som flere steder bruges om Alatiel i den italienske tekst. Se Boccaccio, Decameron. 
de pålagt hende afholdenhed" (II, 7: 140). Novellen hæfter sig ikke meget ved religiøse eller kulturelle forskelle. Alatiel beskrives fx ikke som en eksotisk skønhed (Kahf 63). Kønsforskellen er vigtigere end den etniske forskel: Hvad enten vi er i den islamiske eller den kristne verden fremstilles handelskulturen som en patriarkalsk kultur: "Boccaccio's muslimske kvinder bærer ikke en dobbelt andethed - forskellen ved at være islamisk plus forskellen ved at være kvinde. Kun kønsforskellen er tilbage, og den har de til fælles med skildringen af europæiske kvinder" (Kahf 63). Dog er det påfaldende, at de muslimske mænd Alatiel møder, behandler hinanden uden vold og hjælper hende, mens de vestlige mænd (på nær den første) optræder uciviliseret: "Den civiliserede adfærd er i hænderne på den Anden, mens de kristne er fulde af bedrag, mord, begær og disrespekt overfor kirkelige institutioner" (Smarr 33). Det muslimske motiv fungerer på den måde som et sted, hvorfra teksten kaster et kritisk blik på den kristne kultur. Og jeg vil hævde, at Alatiels muslimske identitet forstærker den ovennævnte kobling af seksuel logik og handelslogik: Det er nærliggende at læse hende som et billede på de orientalske luksusvarer, skibene sejlede med og som man efterstræbte i Vesten. En vare hvis værdi ikke blev mindre af at være blevet nydt undervejs. Det er mændenes blinde begær efter varen, der straffes, og novellen - der fletter sex og handel sammen - dømmer de to temaer forskelligt: Seksualiteten bliver hyldet og sat fri, mens der bliver advaret mod handel og lagt op til, at den bør kontrolleres.

Alle stederne på Alatiels rejse har været datidens læsere bekendte og fremkaldt politiske, økonomiske og kulturelle associationer til Italiens handel i det øst- og sydlige Middelhav. Alatiels rute havde stor betydning for italienernes, især florentinernes handel: Aleksandria var den vigtigste markedsplads for købmænd fra Afrika, Europa, Indien og den muslimske verden. I det 12. århundrede tiltrak byen kristne købmænd, som købte krydderier, sukker, bomuld og silkestof (Simon 91) og som desuden fik adgang til et stort net af nye handelsruter. Aleksandrias rolle bevidnes af handelsrejsende og pilgrimme, som i nogle tilfælde har efterladt rejsedagbøger: de beundrede byen og fremhævede mangfoldigheden af varer: "Hvis du havde penge i dit bens knogler, ville du uden tvivl ødelægge dem" for at få råd til at købe nogle af alle de ting, der tilbydes, lyder det i en af kilderne (cit. Simon 92). Alatiel forliser på Mallorca, som også var centralt handelscentrum, også for Bardi-fir- 
maet. I novellen er det ikke tilfældigt et genovesisk skib fyldt med varer, der skal transporteres fra Mallorca til Chiarenza, som hun bortføres på. Chiarenza var ligeledes en vigtig handelsplads, hvor især den store florentinske handelsfamilie Acciaiuoli havde en strategisk placeret handelskoloni (Simon 31) og på den græske ø Chios, som Alatiel kommer til med sønnen af kejseren af Konstantinopel, havde de genovesiske købmænd en handelskoloni. Rhodos og Cypern var på kristne hænder og udgjorde i en periode vigtige alternativer til de mellemøstlige handelspladser, som kirken havde forbudt kristne at handle med efter tabet af den sidste korstogsbastion i Akka i 1291 (Simon 84). Intet sted er tilfældigt, og alle de store centre for især den florentinske (og genovesiske) handel nævnes i novellen. Hertil kommer, at flere steder, ligesom Alatiel, har været genstand for erobringer og byttehandler mellem kristne og muslimer. ${ }^{9}$ Fremstillingen af Middelhavet som sted for cirkulation og udveksling af varer mellem mænd fra forskellige kulturer, fortæller indirekte en parallel historie om handel, territorial erobring og politisk ustabilitet i middelhavsområdet på Boccaccios tid. Alt dette er dog ikke for at hævde, at novellens plot er realistisk. Den har, som resten af værket, først og fremmest til hensigt at underholde og at være moralsk belærende.

I den næste historie der skal analyseres, optræder handelskulturen ikke på samme måde som bagvedliggende logik, men har en anderledes direkte funktion i plottet og for den kvindelige hovedperson. På sin vis er der tale om to spejlvendte fortællinger, om to kvinder der religiøst, sprogligt, kulturelt, karaktermæssigt er hinandens modsætninger.

\section{"JEG ER KØBMAND OG IKKE FILOSOF" (II, 9)}

Anden dags niende historie indledes med, at nogle italienske storkøbmænd mødes i Paris, bl.a. Bernabò Lomellin fra Genova, der hævder, at hans kone i modsætning andre kvinder er "prydet med alle de dyder, som passede sig for en frue", hun kan læse og skrive og "føre et regnskab så godt som nogen købmand", hun er smuk, høvisk og klog og kunne ikke finde på at være ham

9 For en yderligere udfoldelse af dette perspektiv, se Kinoshita og Jacobs. De fremhæver bl.a. en historisk konflikt mellem hertugen af Athen og Konstantinopels kejser (177-8). 
utro. Der er "ingen dydigere og kyskere end hun" (II, 9: 174). Ambrogiuolo fra Piacenza fastholder derimod, at kvinden "i enhver henseende er lettere at bevæge" og "af naturen er ustadig" (II, 9: 175) og tror ikke på, at Bernabòs kone adskiller sig herfra. "Jeg er købmand og ikke filosof, svarer Bernabò, og jeg vil derfor svare dig som købmand" (II, 9: 175). De indgår et væddemål på flere tusinde guldfloriner om hvorvidt Bernabòs hustru, Zinevra, vil lade sig forføre af Ambrogiuolo og være sin mand utro eller ej. I Genova får Ambrogiuolo bekræftet rygtet om Zinevras dyd og opgiver, overraskende nok, sin hensigt. Han nøjes, via bestikkelse af en tjener, med at opholde sig længe nok i hendes soveværelse til at betragte hendes nøgne, sovende krop og stjæle nogle af hendes ting, bl.a. en pung og et bælte. Tilbage i Paris 'beviser' han derefter, at han har været i seng med hende og vinder væddemålet. For at straffe sin kone beordrer Bernabò hende dræbt. Den tjener, der skal dræbe hende, bliver imidlertid overtalt af hende til ikke at gøre det og lader hende flygte. Hun får hans tøj, og han tager hendes tøj med tilbage som bevis på drabet. Forklædt som mand og under navnet Sicurano lader hun sig ansætte på et katalansk skib, der transporterer falke ned til den egyptiske sultan. I Aleksandria får sultanen blik for Sicuranos evner, og katalaneren må forære sin tjener (Sicurano) som gave til sultanen: "i løbet af kort tid vandt Sicurano ikke mindre venskab og yndest hos sultanen end hos sin forrige herre" (II, 9: 180). Under det årlige marked i Akka får Sicurano til opgave at være kaptajn over de vagter, der skal kontrollere sultanens varer. På markedet opdager hun sin pung og sit bælte og ejeren, Ambrogiuolo fra Piacenza. Dernæst lokker hun sin mand til Aleksandria, og med hjælp fra sultanen afslører hun Ambrogiuolo og sørger for, at han får en (døds)straf for at have snydt hende. Til slut rejser hun hjem til Genova med sin mand med et stort gavebeløb fra sultanen og efter at have 'arvet' Ambrogiuolos penge og andre værdier (II, 9: 185). Den kristne købmand som bliver sultanens ven og protegé, er et litterært topos, som også optræder andre steder i Decameron, fx i V, 2, hvor Martuccio bliver ven af kongen af Tunis og i X, 9, hvor Torrello bliver ven med sultan Saladin.

Det er takket være handelsaktiviteter - væddemål, handelsskibe, markedspladser - at plottet drives fremad: Handel ligger bag relationerne mellem de italienske mænd, der vædder om Zinevras kyskhed, og vinderen 'sælger' hende i overført forstand, som var hun en genstand. Handel skaber 
dernæst kontakt mellem Zinevra og sultanen i Egypten og er omdrejningspunkt for udviklingen af deres forhold.

Novellen har flere ligheder med Alatiel-novellen: Strukturen i begge noveller er bygget op omkring rejsen. De kvindelige hovedpersoner krydser Middelhavet og ankommer til en fremmed kultur - for derefter at vende hjem igen. Begge kvinder er underlagt en patriarkalsk, grisk og aggressiv handelslogik, der behandler dem som en genstand, man(d) kan bestemme over og udveksle imellem sig. De tilpasser sig begge deres omskiftelige skæbne og overtager i novellernes sidste del styringen af deres liv, hvormed de ender med at få deres ægtemand (og lykken) tilbage. Begge noveller forholder sig deskriptivt og ufordømmende til muslimsk kultur, og deres perspektiv er kulturelt og socialt frem for religiøst. Desuden fortæller anden dags syvende novelle, ligesom Alatiel-novellen, en parallel historie om handelskulturens betydning for Italien via steder og personer: Købmændene rejser til Paris, Aleksandria og Akka. Aleksandria beskrives som en kosmopolitisk by og et mulighedernes land for de italienske købmænd: under sin inspektion på torvet møder Zinevra "mange sicilianske, pisanske, genuesiske og venetianske købmænd og andre italienere" (II, 7: 181), og hun ser sine ejendele i et af de venezianske købmænds varelagre, en "fondaco". ${ }^{10}$ At de to mænd kommer fra henholdsvis Genova og Piacenza (som tilhørte Venedig), er ikke et tilfælde: Det var to af tidens største italienske - og rivaliserende - handelsstater, og Bernabò tilhører endda Lomellini-familien, som var en kendt genovesisk købmandsslægt (Simon 106). ${ }^{11}$ Endelig har Aleksandria derudover en symbolsk betydning i denne novelle som sted for rigdom, generøsitet og retfærdighed: her, i særdeleshed ved sultanens

10 I den danske tekst bliver begrebet "fondaco" oversat med "bod". Det kan dog også betegne de lagre eller magasiner til opbevaring af varer, som de muslimske handelsbyer tillod visse kristne at have. Der var ikke tale om, at kristne købmænd fik hele kvarterer i Tunis eller Aleksandria, sådan som de fik i kristne lande, men blot en lille ' $\varnothing$ ' i den muslimske virkelighed. Ifølge Abulafia var kontakterne mellem de kristne købmænd og de lokale beboere i Tunis og Aleksandria ikke særligt tætte, og de kristne nød ikke de samme privilegier som de lokale beboere (3ff).

11 Simon hævder endvidere, at Sicuranos navn måske er inspireret af en historisk person, en storkøbmand fra Genova, Segurano Salvaygo, som i 1320'erne var i tjeneste hos den egyptiske sultan og som hjalp sultanen med at transportere slaver fra det sorte hav til Egypten (107-8). 
hof, opnår Zinevra moralsk oprejsning, og hun og hendes mand kan vende "glade og rige" tilbage til Genova.

Trods lighederne er de to noveller samtidig spejlvendte: Kvinderne rejser i modsat retning af hinanden og af modsatrettede grunde: henholdsvis for at få en ægtemand og for at flygte fra en ægtemand. Den ene er kristen, den anden muslim. Den ene er kysk, den anden udviser glæde ved sex. Zinevra overlever ved at give afkald på sit køn, blive en mand og lære et fremmed sprog, mens Alatiel overlever ved at give afkald på sit sprog og blive ren kvinde(krop). Alatiel-novellen er narrativt mere kompleks på grund af indlejringen af forskellige fortællinger og langt flere personer, og fordi hovedpersonen er tvetydig i synet på sin egen skæbne. Historien om Zinevra rummer flere beskrivelser af den muslimske verden som konkret sted for handel og sociale relationer ikke mindst det venskabelige forhold til den muslimske sultan, der bygger på gensidig tillid.

\section{KONKLUSION}

Decamerons geografi fortæller en historie om betydningen af handel i middelhavsområdet og mange af novellerne - herunder de to jeg har valgt som genstand for denne artikel - handler også om handel. De er præget af periodens handelskultur i deres tematiske indhold og narrative struktur. Derudover tematiserer de to noveller kulturmødet mellem Italien og den islamiske verden, og viser at handel skaber kontakt på tværs af religiøse forskelle og politiske konflikter. De tegner dermed et andet billede end den "stereotype araber" og religiøse-ideologiske fjende, som man ser i tidligere korstogsberetninger og epos (Kirkham \& Menocal 97), og end det billede, man finder hos Dante og især Petrarca. I Boccaccios noveller fordømmes den orientalske verden ikke som kulturelt eller religiøst anderledes. Det islamiske (mellemøstlige eller nordafrikanske) rum er hverken udlagt for erobring eller fremstillet som en trussel mod vestens integritet, men et sted for respektfuld etablering af handelsmæssige kontakter, venskaber, elskov og rigdom.

Denne skildring af muslimer er ikke alene resultatet af periodens merkantile kultur, som præger middelhavsområdet og sætter fortjeneste over religiøse forskelle. Den hænger også sammen med valget af litterær 
genre: Ifølge den implicitte forfatters eget udsagn i værkets fortale er formålet med novellerne at underholde læserne og at være nyttige i moralsk henseende. Seriøse emner som religion og politik skulle behandles i traktater, historiske afhandlinger eller breve, der henvendte sig på latin til lærde målgrupper. Når Boccaccio forholder sig til islam som religion i sine lærde værker, omtaler han da også islam i mere negative vendinger og peger frem mod den holdning, som renæssancehumanisterne udtrykte i perioden umiddelbart derefter - dvs. en stærk fordømmelse af islam og tyrkerne både ud fra et kulturelt og religiøst perspektiv. ${ }^{12}$ Det tematiske indhold er således determineret af genren. I Decameron optræder den islamiske verden som et sted, hvorfra der omvendt indirekte kan kastes et kritisk blik på Europa: Den positive skildring af den hverdagslige, arabiske verden fungerer som et spejl, en slags borgerskabets spejl, der udover at underholde også har en belærende funktion og holdes op foran de kristne læsere i håb om, at de erkender deres egen grådighed og de uetiske konsekvenser af handelskulturen. Værket er skrevet for købmænd og ikke filosoffer.

Pia Schwarz Lausten, cand. mag., PhD., lektor i italiensk litteratur ved Institut for Engelsk, Germansk og Romansk, Københavns Universitet. Har blandt andet udgivet artiklerne "'... experience is certainly worth more than theory': Images of the Turk in Italian Sixteenth Century Writings". In Bent Holm og Mikael Bøgh Rasmussen (red.) Imagined, Embodied and Actual Turks in the Early Modern Era (under udgivelse) og "Saracenere og tyrkere i Ludovico Ariostos Orlando Furioso". In Pia Schwarz Lausten (red.) Turban og Tiara: Renæssancehumanisternes syn på islam og tyrkerne. 2016.

\section{"I AM A MERCHANT AND NOT A PHILOSOPHER"}

Sex, Commerce, and Friendship between Christians and Muslims in Boccaccio's Decamaron

This article investigates the function of trade in the representation of Muslims and Islamic culture in Giovanni Boccaccio's Decameron (1348-52). It is argued that trade establishes friendly contacts across religious and cultural differences, that the image of Muslims is less condemning than is case of 
Boccaccio's contemporaries Dante and Petrarch, and that the Oriental world is represented as a place in which the Christians become rich and successful. Sometimes the Muslim world is indirectly represented as a place from which a critical view of Europe can be thrown. The article analyses two stories in particular: the second day's seventh story about Saracen princess Alatiel who, despite having had sex ten thousand times with eight lovers, successfully presents herself to the King of the Algarve as his virgin bride, and the seventh day's ninth story about Zinevra who escapes from her revengeful husband and travels to Aleksandria disguised as a male merchant. In different ways the stories merge sexual and trade logic. Boccaccio's stories are not considered as realistic sources to get knowledge about the medieval world, but the article argues that geographical references to medieval trade centres and routes show that the stories are influenced by the merchant culture thematically and structurally.

\section{KEYWORDS}

EN: Decameron, trade, Muslims, geography, gender

DK: Decameron, handel, muslimer, geografi, køn

\section{LITTERATUR}

Abulafia, David. "The Role of Trade in Muslim-Christian Contacts during the Middle Ages". The Arab Influence in Medieval Europe. Red. Dionisius Agius og Richard Hitchcock. Reading: Ithaca Press, 1994: 1-24.

Alighieri, Dante. Den guddommelige komedie. Dansk oversættelse ved Ole Meyer. København: Multivers, 2000.

Asor Rosa, Alberto. "Decameron di Giovanni Boccaccio". Storia della letteratura italiana. Torino: Einaudi, 1992: 473-555.

Bérard, Claude C. "Filoginia/misoginia". Lessico critico decameroniano. Red. Renzo Bragantini og Pier Massimo Forni. Torino: Bollati Boringhieri, 1995: 116-141.

Boccaccio, Giovanni. Decameron. A cura di Vittore Branca. Torino: Einaudi, 1992.

Boccaccio, Giovanni. Dekameron. Uforkortet oversættelse ved J.V. Lind. Bind 1-3. København: Nyt Nordisk Forlag, Arnold Busck, 1960.

Boccaccio, Giovanni. "De casibus Virorum Illustrium". Tutte le opere di Giovanni Boccaccio. Vol. IX. Milano: Mondadori, 1983.

Boccaccio, Giovanni. "Esposizioni sopra la Comedia di Dante". Tutte le opere di Giovanni Boccaccio. Vol. VI. Milano: Mondadori, 1965. 
Branca, Vittore. Boccaccio medievale e nuovi studi sul Decameron. Firenze: Sansoni editore, 1996.

Cerbo, Anna. "Cultura e religione islamica nella letteratura italiana del trecento". Europe and Islam between 14th and 16th Centuries. Napoli: Istituto Universitario, 2002: 1-67.

Flasch, Kurt. Poesia dopo la peste. Saggio su Boccaccio. Bari: Editore Laterza, 1995.

Gittes, Katharine Slater. "The Canterbury Tales and the Arabic Frame Tradition". PMLA 98 (1983): 237-51.

Kahf, Mohja. Western Representations of the Muslim Woman. From Termagant to Odalisque. Austin: University of Texas Press, 1999.

Kinoshita, Sharon og Jason Jacobs. "Ports of Call: Boccaccio's Alatiel in the Medieval Mediterranean". Journal of Medieval and Early Modern Studies. 37:1 (2007): 163-195.

Kirkham, Victoria og María Rosa Menocal. "Reflections on the 'Arabic' World: Boccaccio's Ninth Stories". Stanford Italian Review, VII (1987): 95-110.

Larner, John. Italy in the age of Dante and Petrarch, 1216-1380, London: Longman, 1980.

Lausten, Pia Schwarz. "Renæssancehumanisterne og tyrkerne: Indledning". Turban og Tiara. Renæssancehumanisternes syn på islam og tyrkere. Red. Pia Schwarz Lausten. København: Vandkunsten, 2016: 7-25.

Lausten, Pia Schwarz. "'Alt bliver til i strid': Petrarcas korstog mod arabisk kultur og islam". Turban og Tiara. Renæssancehumanisternes syn på islam og tyrkere. Red. Pia Schwarz Lausten. København: Vandkunsten, 2016: 58-86.

Madsen, Peter. "Indledning". Tusind og én Nat: Bind I. Oversat af Ellen Wulf. København: Vandkunsten, 2013: xxxi-lxxi.

Marcus, Millicent: "Seduction By Silence: A Gloss on the Tales of Masetto (Decameron III, 1) and Alatiel (Decameron II, 7)". Philological Quarterly, 58:1, (1979): 1-15.

Menocal, María Rosa. The Arabic Role in Medieval Literary History. A Forgotten Heritage. Pennsylvania: University of Pennsylvania Press, 1987.

Nervo, Francesca Rizzo. "Percorsi della cornice narrativa". Medioevo romanzo e orientale. Il viaggio dei testi. Red. A. Pioletti \& F.R.Nervo. Cosenza: Rubbettino editore, 1999: 251-259.

Picone, Michelangelo. "Tre tipi di cornice novellistica: modelli orientali e tradizione narrativa medievale". Filologia e critica, 12 (1988): 3-26.

Picone, Michelangelo. "Dal romanzo antico alla novella medievale: Decameron II.7". Der Antike Roman und seine mittelalterliche Rezeption. Red. Michelangelo Picone og Bernhard Zimmermann. Basel: Birkhäuser, 1997: 321-39.

Pioletti, Antonio. "Della tipologia della cornice narrativa". Poetica medievale tra oriente e occidente. Red. P. Bagni og M. Pistoso. Roma: Carocci, 2003.

Procacci, Giuliano. Storia degli italiani. Roma: Laterza, 1998.

Ricci, Lucia Battaglia. Boccaccio. Roma: Salerno editrice, 2000.

Simon, Anita. Le novelle e la storia. Toscana e Oriente fra tre e quattrocento. Roma: Salerno edtrice, 1999.

Smarr, Janet Levarie. "Non-Christian People and Spaces in the Decameron". Approaches to Teaching Boccaccio's Decameron. Red. James H. McGregor. New York: The Modern Language Association of America, 2000: 31-38. 
70 KULTUR \& KLASSE * $124 * 2017$ HANDEL

Taylor, Mark. "The Fortunes of Alatiel: A Reading of Decameron 2,7". Forum Italicum, vol. 35:2, (2001): 318-331.

Toftgaard, Anders. Novellegenrens fødsel - fra Il novellino til Decameron. København: Museum Tusculanum, 2005.

Varvaro, Alberto. "Forme di intertestualità. La narrativa spagnola medievale tra Oriente e Occidente". Annali, sezione romanza, 17:1 (1985): 49-65.

Ziolkowski, Jan M. Dante and Islam. New York: Fordham University Press, 2015. 